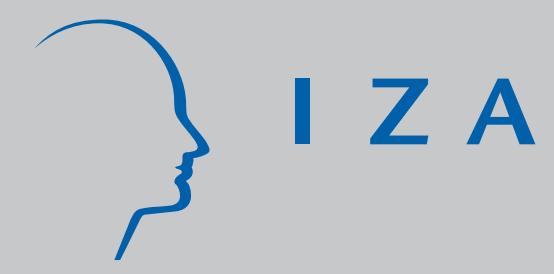

IZA DP No. 863

Immigrant Religious Adjustment:

An Economic Approach to J ewish Migrations

Carmel U. Chiswick

August 2003 


\title{
Immigrant Religious Adjustment: An Economic Approach to Jewish Migrations
}

\author{
Carmel U. Chiswick \\ University of Illinois at Chicago \\ and IZA Bonn
}

Discussion Paper No. 863

August 2003

\author{
IZA \\ P.O. Box 7240 \\ D-53072 Bonn \\ Germany \\ Tel.: +49-228-3894-0 \\ Fax: +49-228-3894-210 \\ Email: iza@iza.org
}

This Discussion Paper is issued within the framework of IZA's research area Mobility and Flexibility of Labor. Any opinions expressed here are those of the author(s) and not those of the institute. Research disseminated by IZA may include views on policy, but the institute itself takes no institutional policy positions.

The Institute for the Study of Labor (IZA) in Bonn is a local and virtual international research center and a place of communication between science, politics and business. IZA is an independent, nonprofit limited liability company (Gesellschaft mit beschränkter Haftung) supported by Deutsche Post World Net. The center is associated with the University of Bonn and offers a stimulating research environment through its research networks, research support, and visitors and doctoral programs. IZA engages in (i) original and internationally competitive research in all fields of labor economics, (ii) development of policy concepts, and (iii) dissemination of research results and concepts to the interested public. The current research program deals with (1) mobility and flexibility of labor, (2) internationalization of labor markets, (3) welfare state and labor market, (4) labor markets in transition countries, (5) the future of labor, (6) evaluation of labor market policies and projects and (7) general labor economics.

IZA Discussion Papers often represent preliminary work and are circulated to encourage discussion. Citation of such a paper should account for its provisional character. A revised version may be available on the IZA website (www.iza.org) or directly from the author. 
IZA Discussion Paper No. 863

August 2003

\section{ABSTRACT}

\section{Immigrant Religious Adjustment: An Economic Approach to Jewish Migrations*}

An economic theory of immigration and immigrant absorption for a religious minority is developed and applied to Jewish history. Human capital is classified according to whether it is allocative or productive, transferable or location-specific, general or Jewish. Crossclassifying these categories leads to various hypotheses about self-selection among Jewish immigrants and their influence on the Jewish community in their destination. Complementarity between general and Jewish human capital is also discussed as a factor in the development of location-specific Jewish human capital and its corresponding Jewish culture.

JEL Classification: N30, J61, and Z12

Keywords: $\quad$ migration, immigrant adjustment, religion, Judaism, minority ethnic groups

Carmel U. Chiswick

Department of Economics (m/c 144)

University of Illinois at Chicago

601 S. Morgan Street

Chicago, Illinois 60607-7121

USA

Tel.: +1 3129968721

Fax: +1 3129963344

Email: cchis@uic.edu

\footnotetext{
* As international migrations become a common feature of modern life, there is an unresolved tension between assimilation into the destination community and preservation of origin cultures. This study views the long-run history of Jewish experience with migration as a case study in the economics of minority religious adjustment. While the illustrative material refers exclusively to Judaism and Jews as a religious community, the theory is more generally applicable to a wide variety of immigrant groups and minority cultures.
} 


\section{Introduction}

Jewish history is replete with the stories of immigrants: individual wanderers or entire communities, sometimes a search for adventure or for greater wealth, but often in a desperate bid for safety. This paper develops an economic model of immigrant religion and applies it to an overview of Jewish history. The model is derived from recent work on the economics of immigration, of immigrant absorption, and of immigrant religions in the United States. The historical scope is broad, covering European Jewry during the last 1,000 years or so from the early Middle Ages through the present. While the economic theory may also apply to other religious minorities, it yields important insights into a central feature of Jewish history. The present paper may thus be viewed as a prospectus for further studies revisiting the migration history of the Jews.

Religion is a non- market good, like family life or leisure, which must be self-produced by each consumer. The product itself - in this case, Judaism - may be characterized in terms of the spiritual and social life of the individual, the strength of the community and its institutions, and the intergenerational continuity of the Jewish People. Any Jewish activity may be thought of as a deployment of resources towards one or more of these goals, a "production" process that combines purchased goods and services with the consumer's own time to achieve a Jewish experience.

A person's Jewish human capital is the set of previously acquired personal traits - memory, experience, skill - that enhance the efficiency of time spent in specifically Jewish activity. ${ }^{1}$

\footnotetext{
${ }^{1}$ Human capital may be specific to activities of a single religion or ethnic group or it may be generally productive for activities pursued by members of all groups. Jewish human capital would include only those skills that enhance efficiency in producing specifically Jewish goods or services or in activities specific to Judaism and the Jewish community. All other human capital will be viewed here as "general" since the human capital of non-Jewish groups is
} 
These may be subdivided into two types: production and allocative human capital. ${ }^{2}$ A Jewish production skill would include anything that raises productivity in specific activities, such as knowledge of Hebrew or familiarity with ritual. Allocative skill is anything that improves an individual's decision-making ability in Jewish matters, thus enhancing the efficiency with which religious resources are deployed. An example of Jewish allocative skill might be the wisdom required to decide questions about Shabbat observance or kashrut (dietary laws) by applying traditional rulings to new circumstances. Allocative human capital is especially important among immigrants, whose adjustment to a new environment puts a premium on an ability to distinguish the essential - whether spiritual or communal - from the superficial and to accurately weigh the costs and benefits of change.

The organization of this paper is as follows. Part II presents the basic theoretical principles underlying the economic analysis of immigrant adjustment, extending them to apply to absorption into the Jewish community as well as the destination economy. Part III uses these principles to develop hypotheses about self-selection among Jewish immigrants and their implications regarding the balance between tradition and innovation in Jewish life. Part IV discusses some ways in which the immigrant experience impacts the evolution of Judaism itself as communities in various destinations adapt to different environments. Part V concludes with a brief summary of implications.

irrelevant to this analysis. As with any two productive inputs, Jewish and general human capital are simultaneously both complements and substitutes (C. Chiswick, 1999).

${ }^{2}$ See Schultz (1975) for the development of the distinction between productive and allocative human capital. 


\section{The Jewish Human Capital of Immigrants}

\section{A. Transferability of Jewish Human Capital}

The various types of human capital may be classified according to the context in which they are productive. A "location-specific" skill, whether production or allocative, would be one for which efficiency gains are limited to a particular place and time period. Mastery of a parochial language, for example, would be useful only where that language is spoken; skills that might be very valuable in the bazaars and courts of the Ottoman Empire might be useless or even counterproductive in the legal environment of England or the United States. In contrast, skills such as carpentry, mathematics and medicine would be productive in many places and thus "transferable" across different environments.

Transferability of Jewish skills can be evaluated with respect to the general society as well as within the Jewish community in the destination. In each location, adaptations of Jewish practice to local socio-economic conditions give rise to differences in Jewish customs and religious observance. For example, two Jewish communities with the same traditional synagogue prayer service might adapt their liturgical melodies to conform to the local culture, in which case familiarity with the prayers would be a transferable form of Jewish human capital but familiarity with the melodies would be location-specific. Complementarities between Jewish and general human capital may also differ, giving rise to differences between Jewish observance in different communities. For example, if one Jewish community were surrounded by a culture emphasizing mysticism and spirituality and another by a culture emphasizing rationality and science, the emphasis in Jewish culture will probably reflect similar differences. Judaism has developed a wide variety of location-specific expressions, with corresponding forms of Jewish human capital, in response to many different socio-economic environments across time and space. Yet the common core of Jewish experience shared by all Jewish communities - that is, 
the human capital that defines their Jewishness - would be largely transferable within the sphere of Jewish activity.

If origin-specific skills (that is, location-specific skills from the place of origin) have no value in the destination, people with large investments in origin-specific skills have more to lose by emigrating and are less likely to do so. For the same reason, prospective migrants are likely to invest relatively more in skills that will transfer to their destination. Immigrants typically wait until after their arrival in the destination before investing heavily in destination-specific human capital, however, since these tend to be more difficult (expensive) to acquire in places where they are not used. Immigrants thus tend to be self-selected for high skill transferability relative to non- migrants both in the origin and in the destination. Imperfect transferability of skills is the main reason why new immigrants are at an earnings disadvantage relative to natives with otherwise similar labor force characteristics. ${ }^{3}$ Post-migration investments in location-specific human capital are especially heavy in the early years and lead to absorption into the destination economy and erosion over time of an immigrant's initial earnings disadvantage (B. Chiswick, $1978 ; 1979)$.

Similar principles apply to investments in location-specific religious human capital. Jewish immigrants would have an incentive to self-select for relatively low origin-specific Jewish skills, whether because the individual has few Jewish skills in general - from lack of Jewish education or low religious attachment - or whether because the Jewish skills are of a type that is readily transferable. All Jewish communities share a Hebrew-based common core, sometimes referred to as Judaism's “Great Tradition," but Jewish life may differ across time and space with more

${ }^{3}$ For many immigrants language is the most important example of location-specific human capital. Lack of proficiency in the destination language contributes to the earnings disadvantage of new immigrants, and rapid acquisition of language skills greatly speeds the absorption process. 
location-specific "Small Traditions." For example, refraining from work on the Sabbath is part of the Great Tradition, but the menu for a "traditional" Sabbath meal is part of the Small Tradition. Many synagogue prayers belong to the Great Tradition, but the melodies to which they are sung or chanted may differ by Small Tradition.

Fluency in the Hebrew language is a highly-valued skill that is widely transferable between Jewish communities, as is familiarity with Jewish Scriptures, with the liturgy, and with the basic laws of kashrut (dietary observance). Local Jewish languages and customs would be less transferable. Yiddish, for example, was the language of Ashkenazi (non-Mediterranean European) Jewry for nearly a thousand years, primarily in Christian countries. During that same period Sephardi Jews, who lived in Mediterranean Europe and the primarily Moslem lands of

North Africa and the Near East, spoke the Jewish language Ladino. Each of these major Jewish languages was specific to their respective Jewish cultures but highly transferable among communities within them, with Hebrew serving as the common language of both. Jewish migration would thus have been much easier within these common-language areas rather than between them

\section{B. Jewish Enclaves, Outposts and Expatriate Communities}

For immigrants who intend to settle permanently in the destination, absorption into a new Jewish community typically involves post-migration investments in destination-specific Jewish human capital. For some this is facilitated by dispersing into a destination-specific environment, both general and religious. Others, however, find it easier to adjust by reaching out to other immigrants of the same origin, forming an enclave community perhaps even with its own synagogue. Old-country religious institutions are a typical feature of many immigrant communities, providing an island of familiar experience in an otherwise "foreign" environment and a place where origin-specific skills (such as language, ritual, etiquette) can still yield benefits 
(Warner, 1998). Despite their apparent parochialism, immigrant religious institutions often facilitate absorption into the destination country by providing a comfortable haven where communication is easy and problems can be shared. Immigrant religious and social institutions are typically transitional, however, evolving into forms more compatible with the socioeconomic environment as their members acquire destination-specific human capital. Most immigrant religious institutions survive only for a generation or two.

Unlike permanent immigrants, temporary or short-term migrants expect their migration experience to end after a finite period, at which time destination-specific human capital would lose its value and origin-specific skills would again be useful. Temporary migrants thus have less incentive to invest in destination- rather than origin-specific human capital and a greater incentive to exercise their origin-specific skills to retard depreciation during their sojourn abroad. This is facilitated by forming an expatriate community, resembling the immigrant community in many ways but serving a very different function. Traditional expatriate communities might contain members of the origin-country's diplomatic service, commercial representatives, migrant laborers, and political or religious exiles awaiting a change in regime. These form a foreign enclave in the host country, developing institutions in the destination where origin-specific human capital can be used and preserved. Unlike the immigrant communities, however, their purpose is not to aid absorption but rather to shield their members from the consequences of incomplete absorption. The human capital of children raised in an immigrant enclave may also have a large origin-specific component, perhaps in anticipation of their eventual repatriation, which further retards the community's absorption in the destination.

Historically, Jewish migrations have been of both types. There are many examples of places where Jewish scholars, merchants, or adventurers have sojourned long enough to form new 
settlements, retaining the customs of their origin culture and sustaining this connection with commercial relations and religious correspondence. There are also many examples of Jewish migrations that severed ties with the origin-country, sometimes because of persecution or expulsions but also because of the opening up of a new opportunity. Human capital theory suggests that Jewish culture is most likely to be conservative - in the sense of preserving the origin-community's traditions - in the former and most likely to be innovative in the latter.

On a religious level, however, all Jews are expatriates from Eretz Yisrael (the Land of Israel), the national origin - however remote - of the Jewish People. ${ }^{4}$ Jewish religious observance preserves the language of this origin country (Hebrew), uses origin-specific objects in its ritual (e.g., Torah scrolls), and retains origin-specific concepts in its liturgy (e.g., longing for Zion and Jerusalem). Weekly readings from the Hebrew Bible (Torah) include detailed descriptions of rituals performed in the Temple in Jerusalem, even though these rituals must not be performed anywhere else and have not been performed for nearly 2000 years. Familiar prayers and even the annual cycle of Jewish holidays refer to the agricultural seasons of the origin country and to the specific expectation of eventually returning to Jerusalem, further reinforcing a self-concept of exile. In religious matters, all Jewish communities - especially those located outside of the Land of Israel - are expatriate communities.

In this context, even Jews who are permanent migrants or even native to the destination country retain some of the incentives and hence characteristics of an expatriate community. Jewish human capital associated with the Great Tradition is highly transferable among Jewish communities, and immigrants have an incentive to maintain this transferability even as they have

\footnotetext{
${ }^{4}$ The religious concept of Eretz Yisrael is distinct from Medinat Yisrael, a political concept referring to the modern-day State of Israel. The Land of Israel has religious significance for Jews regardless of its sovereignty, and the significance of the modern Jewish State is greatly enhanced by its location in that land.
} 
an incentive to find new adaptations specific to the destination. This is not a new phenomenon but one deeply embedded in Jewish life from its inception. Jewish religious literature (e.g., Torah, Talmud and responsa) constantly returns to this theme, probing issues associated with finding the optimal balance between adaptation and tradition. Study of these traditional sources helps develop Jewish-specific allocative skills for negotiating a religious world that is simultaneously both expatriate and indigenous.

\section{Jewish Human Capital of Immigrants: Some Hypotheses}

The immigrant economic experience permeates Jewish history. In part this is because of the many expulsions and persecutions to which Jews have been subjected over the course of the centuries, each of which has forced its survivors to choose a destination and adjust to its socioeconomic environment. Yet there have also been long periods of relative security during which Jews have migrated voluntarily, as individuals or as families, for the usual reasons - commerce, marriage, opportunity, adventure. The following hypotheses about the geographic and social mobility of Jews in various times and places are suggested by the human capital principles outlined in the previous section.

Hypothesis 1: People with high levels of transferable Jewish human capital are most likely to move from one Jewish community to another and least likely to assimilate.

People with high levels of transferable Jewish human capital would include, for example, Torah scholars (including, of course, those who study Talmud) and those who officiate in various aspects of Jewish religious life. Such persons might be employed primarily within the Jewish community itself, with remuneration in the form of money wages, wages in kind (e.g., room and board, comfortable working conditions), or non-pecuniary rewards (e.g., spiritual gratification, intellectual stimulation, social status). The y might be expected to migrate to a Jewish community where their productivity would be especially high (perhaps because of 
complementary resources) or where demand for their services is relatively high (perhaps because of greater commitment or greater wealth).

The centers of Jewish scholarship have moved over the centuries with the fortunes of their Jewish communities and the larger societies in which they reside, but each has served as a magnet drawing immigrants from a wide hinterland. Each in their own time, Tiberias and Babylon, Troyes and Safed, Vilna and New York supported Jewish academies that drew immigrants as both teachers and students. Other communities would correspond with these centers, or perhaps bid for a Rabbi to live with them, because the human capital in which they specialized was highly transferable throughout the Jewish world.

Hypothesis 2: Among immigrants with high levels of Jewish human capital, those with high allocative skill are most successful in their modifications of Jewish observance.

Jewish culture relies on its most respected scholars for guidance as to whether proposed changes in religious observance are desirable, acceptable, or even permissible. Yet even the most erudite scholars may differ on this score, and each may have a following among ordinary people in the Jewish world. To be successful an innovation must not only be accepted by contemporaries, it must also somehow strengthen the community in the long run and persist across generations. Innovations that reduce the full cost of religious observance in the short run may be very popular, but they may also incur some long-run costs like failing to preserve the Great Tradition. A suboptimal adaptation in Jewish practice that leads to schism or assimilation, if not initially then perhaps by the children and grandchildren, undermines the community even to the point of disappearance. By this criterion, any religious innovation that survives as Jewish is ipso facto successful.

A higher level of allocative efficiency can be inferred for those scholars whose analysis revealed an understanding of the value of changes that in retrospect were successful. A low level 
of allocative efficiency can be attributed to scholars who favored higher-cost forms of Judaism, whether because they resisted change inefficiently or because they supported inefficient changes. The ability to evaluate empirical observation and analyze it successfully for implications is an important characteristic of both Jewish and general allocative human capital. People with very high levels of allocative human capital could thus be expected to exhibit entrepreneurial success in both spheres of activity.

An example that immediately comes to mind is Moses ben Maimon, a brilliant twelfthcentury scientist, physician, philosopher, and Torah scholar. Known as Maimonides in the secular world and as the Rambam ${ }^{5}$ among Jews, he was born to a scholarly family in Cordoba, Spain in 1138. By the age of twenty-one he had lived through the conquest of Christian Spain by unfriendly Moslems, had published his first scholarly work, and had immigrated with his family to the more friendly Moslem environment of Fez, Morocco. He immigrated to Egypt in his late twenties, where he spent most of his adult life as a prominent physician (his most famous patient being the Sultan) and leader of the Jewish community. Among his other work - which included treatises on medicine and astronomy - he wrote an extensive commentary on the Torah and an innovative manual for Jewish observance (Guide for the Perplexed) that was both influential and controversial throughout the Jewish world.

Maimonides is perhaps the best-known example, yet other distinguished Jewish scholars have also participated in the worlds of science, philosophy, commerce and art, and many if not most of them participated in the immigrant experience as well. Negotiating these different spheres successfully would have required high levels of allocative skill in general, and it is reasonable to suppose that this skill was transferable to the religious sphere for assessing

\footnotetext{
5 The title "Rambam" is an acronym for "Rabbi Moshe Ben Maimon."
} 
tradeoffs between change and tradition. Hypothesis 2 suggests that among Jewish religious leaders the ones with such "dual careers" would have been most successful in discerning changes in Jewish practice that would not only reduce its cost but also preserve or even increase its integrity.

Hypothesis 3: Groups of immigrants with ordinary Jewish human capital, or with low levels of allocative Jewish skills, are most likely to form an outpost of their origin-country Jewish community.

Economic migrants tend to be self-selected for persons with above-average abilities to spot new economic opportunity and to adapt to new environments, and they invest early and heavily in destination-specific general human capital. During this adjustment period their resources are devoted to general adjustment and religious life must rely primarily on transferable Jewish human capital. This is all the more so for refugees, who are often not self-selected for success in the destination and who therefore tend to have a more difficult economic adjustment. It is common for such immigrants to establish their own synagogues and other communal institutions where they can use some of their origin-specific skills, both Jewish and general.

If the migration is permanent and allocative skills are high, the immigrant religious structures are transitional and the community eventually adapts its practice to the destination environment. If allocative skills are low, however, the community may continue to rely on origin-country Jewish authorities for guidance on Jewish practice and change. This has the potential to develop into a long-term relationship in which Jews that are fully assimilated into the general economy of the destination country nevertheless function as an outpost of the origincountry Jewish community.

Such relationships have a long tradition and are part of the structure of rabbinic Judaism. For centuries after the destruction of the Temple in Jerusalem, Diaspora Jewish communities looked to the centers of Jewish learning - Palestine or Babylon, depending on the community's 
origin and location - for authority in Jewish matters. A system of Jewish education emerged that brought the best scholars and students together in relatively few locations. Those who eventually left these centers to serve as leaders in their respective Jewish communities would continue to look to their teachers for advice and often engaged in extensive correspondence. Jewish law would later develop through the collection of Responsa, the written responses of a respected Rabbinic authority to the rabbi of an outlying community on questions of Jewish religious practice. This semi-formal system of Jewish religious governance enhanced the transferability of Jewish human capital within the sphere of influence of a particular authority. Its effectiveness as a religious institution my have been stimulated by the frequent persecution and expulsion of European Jewish communities, leading to the establishment of new immigrant Jewish communities with large refugee populations.

Hypothesis 4: People with high levels of general allocative human capital and low levels of Jewish human capital are most likely to move to destinations on or beyond the frontiers of Jewish life.

Hypothesis 5: Isolated Jewish immigrants with low levels of allocative Jewish skill will either assimilate (if their Jewish production skill is also low) or practice Judaism inefficiently in the new environment.

High allocative skills facilitate adaptation to changes of all sorts and raise the return to migration. Since much of Jewish religious observance requires community, isolated Jewish families without a critical mass of Jewish neighbors are severely restricted in their opportunities for religious participation. ${ }^{6}$ The greater the level of Jewish human capital prior to migration, the greater would be the advantage of choosing a destination in which there are other Jews. Put

\footnotetext{
${ }^{6}$ Traditionally, the minimum for a regular prayer service is ten adult Jewish men (age 13 and over). In Reform and Conservative congregations - mostly in the United States - adult women began to be counted for this purpose in the later decades of the twentieth century. One implication of this change is that the minimum acceptable size for a Jewish community is approximately halved.
} 
differently, migration to a new but Jewishly isolated environment must weigh the economic gains against a loss in the value of Jewish religious skills. People with low levels of Jewish human capital would have less to lose by moving to destinations where Jews are few or dispersed. Such immigrants would also have the least incentive to form a new Jewish community in the destination. In contrast, isolated Jewish immigrants with higher levels of Jewish human capital have a strong incentive to encourage other Jews to migrate and form a new Jewish community.

\section{Immigration and Jewish Community}

Immigrants can be classified by the degree to which their general human capital (presumably dominated by occupation-related skills) is specific to the origin or readily transferable to the destination. Jewish immigrants can also be classified according to whether their Jewish human capital is readily transferable, as it would be, for example, for immigrants highly skilled in the Hebrew-based core of the Great Tradition, or for Jews migrating between communities that share the same Small Tradition. The combination of general and Jewish human capital characteristics has implications not only for the experience of Jewish immigrants but also for the development of a Jewish community in the destination.

Since economic adjustment is relatively easy for immigrants with transferable human capital, they can be expected to participate fully in both general and Jewish life shortly after arrival. Immigrants whose general human capital is origin-specific are at an economic disadvantage upon arrival and can be expected to invest heavily in market-related skills. Adjustment is easier for immigrants whose Jewish skills are transferable since they can more readily fit into the existing Jewish community with its social life, information networks, and 
opportunities for employment in Jewish-specific occupations (e.g., Hebrew teachers, Cantors). In contrast, immigrants with relatively high origin-specific human capital in both spheres have the most difficult time since their absorption requires investments in both general and Jewish skills.

The adjustment of Russian Jews arriving in the U.S. at the turn of the $20^{\text {th }}$ century was of the most difficult sort, requiring investment in destination-specific human capital for both general and Jewish skills. For many, the optimal strategy was to focus on acquiring market-related human capital, postponing heavy investments in destination-specific Jewish skills until they were economically more secure (C. Chiswick, 2001). Others might choose to allocate some of their early investments to Jewish human capital specific to the destination, leading to more rapid absorption into the Jewish community but perhaps a slower economic adjustment. Spanish Jewish immigrants to Ashkenazi communities in Europe after the expulsion of 1492 may have experienced similar difficulties, although many of them may have had more skill transferability in either dimension - for example, if the immigrants were merchants, physicians or diamond cutters or if they had been preceded by prior migrations of Spanish Jews.

Mutual complementarities between Jewish and general human capital also affect the degree and speed of immigrants' adjustment to the destination (C. Chiswick, 1999). Jews living in a society whose general human capital complements positively their Jewish skills find that investments in either sphere have positive spillover effects in the other, increasing the rates of return to investments in both. In such an environment Jewish and general education go hand in hand, as with Maimonides who excelled as both a Torah scholar and a physician in $12^{\text {th }}$-century North Africa. In contrast, the Jews of Russia and most of Europe during the $19^{\text {th }}$ century lived in a society where obtaining a university education was far more difficult for an observant, 
scholarly Jew than for a non-observant student, while at the same time institutions for advanced Jewish study were often intolerant of non-religious subject matter. This would have made general and Jewish human capital anti-complementary, in that displaying high achievements in either sphere could actually reduce the return to investments in the other. Neither of these extremes characterized the U.S. during the $20^{\text {th }}$ century, where complementarities were probably negligible in the sense that Jewish human capital had little effect on secular education and vice versa.

Jewish tradition has a rich variety of expression and institutions accumulated over its long history of minority existence in many different locations. Jewish allocative skills enable each community not only to balance tradition with change, but also to discern which traditions are optimal, maximizing positive complementarities between Jewish and general human capital and minimizing negative ones. Thus Jewish institutions evolve as Jews migrate from one economic environment to another, sometimes by design and sometimes by triatand-error.

The tradeoff between adjustment and tradition, a central theme in Judaism since antiquity, must be evaluated frequently as Jews move from one environment to another or as the environment itself changes with the passage of time. Judaism's ability to survive as a religion, and for the Jewish people to survive as an identifiable group, may be attributable in large part to the relative importance of allocative skill in Jewish human capital. The Torah, the Talmud, and much of Jewish literature in recent times may be seen as a series of "case studies" that raise these issues and illustrate the processes by which adjustments could be made. The development of Jewish allocative human capital is thus embedded in the core of religious law itself, which may in turn be understood as a successful adaptation that has stood the test of time. . 


\section{Conclusion}

This paper has applied a modern economic theory of immigrant human capital to some issues in Jewish history and the development of Jewish culture. The absorption of immigrants into the destination economy is conventionally explained in terms of human capital, where skills are classified according to whether they are productive or allocative and whether they are transferable or location-specific. This paper extends the analysis by considering Jewish skills and the immigrant's absorption into a new Jewish community as well as into the socio-economic

environment of the destination. Having two independent classes of human capital - general and Jewish - complicates the absorption process, yielding different possible outcomes in each dimension. It also generates some suggestive hypotheses about Jewish immigrants and their impact on the evolution of Judaism over time and space.

As immigrants adjust to their new environment, the destination community itself may be altered in the process. The language, customs and skills of the newcomers may find their way into the communal experience. An immigrant enclave may arise, either as a transitory phenomenon or as a more long-lived expatriate community. The economics of immigrant adjustment suggests a structure for analyzing some of the relationships between individual Jewish communities and the World Jewry of which they are a part. 


\section{References}

Chiswick, Barry R. (1978). "The Effect of Americanization on the Earnings of Foreign-born Men." Journal of Political Economy 86(5): 897-921 (1979). "The Economic Progress of Immigrants: Some Apparently Universal Patterns". Contemporary Economic Problems 1979. W. Fellner. Washington, D.C., American Enterprise Institute: 357-399.

Chiswick, Carmel U. (1999). "The Econo mics of Jewish Continuity," Contemporary Jewry 20, pp.30-56.

(2001). "The Economics of Jewish Immigrants and Judaism in the United States." Papers in Jewish Demography 1997, pp.331-344.

Schultz, Theodore W. (1975). "The Value of the Ability to Deal with Disequilibria." Journal of Economic Literature 13:3, pp.827-846.

Warner, R. Stephen and Judith G. Wittner, eds. (1998), Gatherings in Diaspora: Religious Communities and the New Immigration. Philadelphia: Temple University Press, 1998. 


\section{IZA Discussion Papers}

\begin{tabular}{|c|c|c|c|c|}
\hline No. & Author(s) & Title & Area & Date \\
\hline 849 & W. Schnedler & Traits, Imitation, and Evolutionary Dynamics & 5 & $08 / 03$ \\
\hline 850 & $\begin{array}{l}\text { S. P. Jenkins } \\
\text { L. Osberg }\end{array}$ & $\begin{array}{l}\text { Nobody to Play with? The Implications of } \\
\text { Leisure Coordination }\end{array}$ & 5 & $08 / 03$ \\
\hline 851 & J. D. Angrist & $\begin{array}{l}\text { Treatment Effect Heterogeneity in Theory and } \\
\text { Practice }\end{array}$ & 6 & $08 / 03$ \\
\hline 852 & $\begin{array}{l}\text { A. Kugler } \\
\text { M. Kugler }\end{array}$ & $\begin{array}{l}\text { The Labor Market Effects of Payroll Taxes in a } \\
\text { Middle-Income Country: Evidence from } \\
\text { Colombia }\end{array}$ & 1 & $08 / 03$ \\
\hline 853 & $\begin{array}{l}\text { I. Ekeland } \\
\text { J. J. Heckman } \\
\text { L. Nesheim }\end{array}$ & Identification and Estimation of Hedonic Models & 6 & $08 / 03$ \\
\hline 854 & $\begin{array}{l}\text { A. Ferrer-i-Carbonell } \\
\text { B. M. S. Van Praag }\end{array}$ & Income Satisfaction Inequality and Its Causes & 3 & $08 / 03$ \\
\hline 855 & $\begin{array}{l}\text { B. Irlenbusch } \\
\text { D. Sliwka }\end{array}$ & $\begin{array}{l}\text { Career Concerns in a Simple Experimental } \\
\text { Labour Market }\end{array}$ & 1 & $08 / 03$ \\
\hline 856 & D. Sliwka & $\begin{array}{l}\text { Management Incentives, Signaling Effects and } \\
\text { the Costs of Vertical Integration }\end{array}$ & 1 & $08 / 03$ \\
\hline 857 & $\begin{array}{l}\text { M. Francesconi } \\
\text { A. Muthoo }\end{array}$ & An Economic Model of Child Custody & 3 & $08 / 03$ \\
\hline 858 & C. U. Chiswick & $\begin{array}{l}\text { History of Historical Statistics of the United } \\
\text { States }\end{array}$ & 7 & $08 / 03$ \\
\hline 859 & R. Fahr & $\begin{array}{l}\text { Loafing or Learning? The Demand for Informal } \\
\text { Education }\end{array}$ & 5 & $08 / 03$ \\
\hline 860 & $\begin{array}{l}\text { J. Bonke } \\
\text { N. Datta Gupta } \\
\text { N. Smith }\end{array}$ & $\begin{array}{l}\text { Timing and Flexibility of Housework and Men } \\
\text { and Women's Wages }\end{array}$ & 5 & $08 / 03$ \\
\hline 861 & $\begin{array}{l}\text { Y. L'Horty } \\
\text { C. Rault }\end{array}$ & $\begin{array}{l}\text { Inflation, Minimum Wage and Other Wages: An } \\
\text { Econometric Study on French Macroeconomic } \\
\text { Data }\end{array}$ & 1 & $08 / 03$ \\
\hline 862 & $\begin{array}{l}\text { J. T. Addison } \\
\text { C. R. Belfield }\end{array}$ & Union Voice & 3 & $08 / 03$ \\
\hline 863 & C. U. Chiswick & $\begin{array}{l}\text { Immigrant Religious Adjustment: An Economic } \\
\text { Approach to Jewish Migrations }\end{array}$ & 1 & $08 / 03$ \\
\hline
\end{tabular}

An updated list of IZA Discussion Papers is available on the center's homepage www.iza.org. 